$\{$ J.M.J., Vol. 4, No. 3\}

\title{
ON EPIDEMIOLOGY OF MURINE TYPHUS IN SAITAMA 1948, IN NIIGATA 1949 AND MULTIPLE OCCURRENCE OF MURINE TYPHUS IN ONE FAMILY
}

\author{
MASAMI KITAOKA, NOBUYUKI TAKEMORI, AKIRA SHISHIDO \\ AND KEIICHIRO JO
}

National Institute of Health

\begin{abstract}
Epidemic (louse-borne) typhus can clinically and epidemiologically be differentiated from murine (flea-borne) typhus, but the differentiation may sometimes be impossible without the aids of serological tests or isolation of the causative agent. Many typhus-fever-like cases were observed in Saitama and Niigata Prefectures. They first were mistaken as epidemic typhus cases because they were reported one after another from one district, but later they were diagnosed as murine typhus cases by means of serological examinations and rickettsial isolation. Of course, careful survey of their occurrence and their living quarters revealed that they were somewhat different from the epidemic typhus. The multiple occurrence of murine typhus in Saitama Prefecture may be attributable to the rat-control without dusting or spray of DDT on the rat run. Multiple occurrence of murine typhus in one family was reported in Chiba and also in other prefectures. The purpose of this paper is to describe in detail on the multiple occurrence of murine typhus in one district and in one family.
\end{abstract}

A) Murine typhus in Saitama Prefecture

1) Epidemiology: In Hiki-district and in one section of Chichibudistrict, 20 patients with fever and rash were reported during the period from the middle of October to December, 1948. The first case was reported in the middle of October and the second at the beginning of November. The majority of other cases was reported during the period from the middle of November to the end of December, and no report was made after the end of December (Fig. 1). 
Fig. 1 Seasonal occurrence of murine typhus in Saitama Prefecture

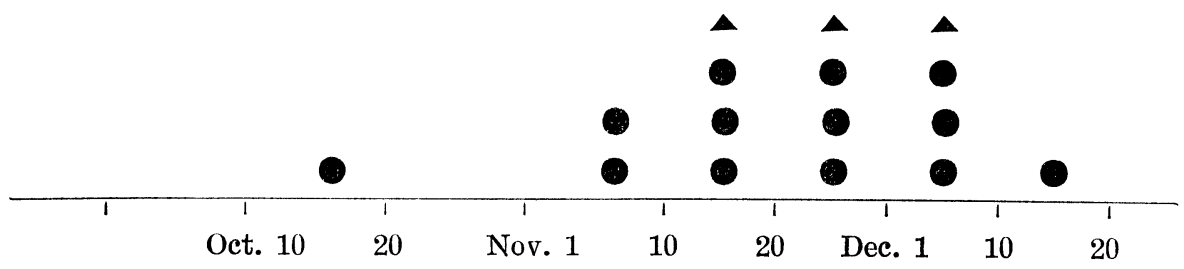

- Patients, who were serologically confirmed to be murin typhus.

$\Delta$ Patients, whose sera showed equal titers against murine and epidemic antigens, or only positive against soluble antigen.

* Number of case every 10 days.

Geographical distribution of those cases was as follows: 6 cases in Ogawa-town, 5 in Okawa-village, 4 in Taira-village and 1 each in Miyamae-, Matsuyama and Takasaka-village of Hiki-district and 2 in Okawara-village of Chichibu-district. The occurrence of those patients was quite sporadical and there was no trace of case to case infection. But there was a family, two members of which (father and his son) suffered from typhus fever. The onset of the disease for the son was Oct. 27th, and that for the father Dec. 1st. The numbers of male and female cases were 10 each. Their age distribution was from 13 to 69 , and most of them were in the range from 20 to 40 years old.

Their occupations were physician, chief of police station, farmer, merchant, student etc. and no relation was found between their occupations and the morbidity. There had been no report, so far, on murine typhus in the districts of Saitama Prefecture. Why did such a number of cases occur during the fall in this area? Rat control without dusting or spray of insecticides like DDT was carried out from the beginning of September and many rats were trapped or killed in the houses of this district. It was pointed out, therefore, that there might exist a high possibility of the inhabitants in this area exposed to the danger of the infection with rat fleas well known as a vector of murine typhus. Rat control should be carried out with some measures to control the exoparasites of rats, too.

2) Serological investigation: Serological tests such as Weil-Felix reaction (WFR), complement fixation test (CFT) and rickettsical agglutination test (R-aggl. T) were performed on 58 serum samples collected from 19 out of 20 clinically suspected typhus cases during the period from 9th to 223rd day of disease (Table 1). 
Table 1

SEROLOGICAL DIAGNOSIS OF MURINE TYPHUS PATIENTS IN SAITAMA PREFECTURE

\begin{tabular}{|c|c|c|c|c|c|c|c|c|c|c|c|c|c|}
\hline \multirow{2}{*}{ No. } & \multirow{2}{*}{ Name } & \multirow{2}{*}{ Sex } & \multirow{2}{*}{ Age } & \multirow{2}{*}{ Occupation } & \multirow{2}{*}{ 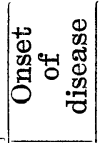 } & \multirow{2}{*}{ 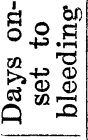 } & \multirow{2}{*}{ 安 } & \multicolumn{3}{|c|}{ C.F.T. } & \multicolumn{2}{|c|}{$\underset{\mathrm{T}}{\mathrm{R}-\mathrm{Aggl}}$} & \multirow{2}{*}{$\begin{array}{c}\text { Isolation } \\
\text { of } \\
\text { Rickettsia }\end{array}$} \\
\hline & & & & & & & & $\mathrm{S}$ & $\mathrm{E}$ & $\mathrm{Mi}$ & $\mathrm{E}$ & $\mathrm{M}$ & \\
\hline 1 & & 우 & 30 & Office girl & $\begin{array}{l}\text { Oct. } \\
15,48\end{array}$ & 19 & 5120 & 640 & 320 & 640 & 320 & 640 & \\
\hline 2 & & 今 & 35 & Doctor & $\begin{array}{l}\text { Oct. } \\
24,48\end{array}$ & & & & & & & & \\
\hline 3 & & 令 & 29 & $\begin{array}{l}\text { Paper-manu- } \\
\text { facturer }\end{array}$ & $\begin{array}{c}\text { Nov. } \\
3,4.8\end{array}$ & 9 & 80 & 0 & 0 & 0 & 0 & 0 & \\
\hline 4 & & 古 & 47 & Farmer & $\begin{array}{l}\text { Nov. } \\
5,48\end{array}$ & 52 & 20 & 640 & 80 & 640 & & & \\
\hline 5 & & 令 & 4.4 & Restaurant & $\begin{array}{r}\text { Nov. } \\
4,48\end{array}$ & 25 & 640 & 160 & 20 & 80 & & & \\
\hline 6 & & 占 & 47 & $\begin{array}{c}\text { Chief of } \\
\text { police station }\end{array}$ & $\begin{array}{l}\text { Nov. } \\
12,48\end{array}$ & 14 & 640 & 320 & 80 & 160 & & & \\
\hline 7 & & 今 & 50 & Grocer & $\begin{array}{l}\text { Nov. } \\
18,48\end{array}$ & 11 & 640 & 160 & 40 & 80 & & & \\
\hline 8 & & 우 & 26 & Farmer & $\begin{array}{l}\text { Nov. } \\
15,48\end{array}$ & 14 & 80 & 0 & 0 & 0 & & & \\
\hline 9 & & 우 & 51 & Farmer & $\begin{array}{l}\text { Nov. } \\
17,48\end{array}$ & 12 & 2560 & 80 & 0 & 0 & & & \\
\hline 10 & & 今 & 48 & Merchant & $\begin{array}{l}\text { Nov. } \\
17,48 \\
\end{array}$ & $\begin{array}{l}26 \\
50\end{array}$ & $\begin{array}{r}5120 \\
640 \\
\end{array}$ & $\begin{array}{r}160 \\
1280 \\
\end{array}$ & $\begin{array}{r}0 \\
80 \\
\end{array}$ & $\begin{array}{r}0 \\
320 \\
\end{array}$ & & & \\
\hline 11 & & 우 & 33 & Farmer & $\begin{array}{l}\text { Nov. } \\
28,48\end{array}$ & 18 & 2560 & 320 & 0 & 0 & & & \\
\hline 12 & & 우 & 16 & Student & $\begin{array}{l}\text { Dec. } \\
1,48\end{array}$ & 36 & 801 & 1280 & 320 & 320 & & & \\
\hline 13 & & 우 & 63 & Farmer & $\begin{array}{l}\text { Nov. } \\
29,48 \\
\end{array}$ & 38 & 3201 & 1280 & 20 & 320 & & & \\
\hline 14 & & 今 & 55 & Official & $\begin{array}{c}\overline{\text { Dec. }} \\
1,48\end{array}$ & $\begin{array}{l}15 \\
36 \\
\end{array}$ & $\begin{array}{r}2560 \\
320 \\
\end{array}$ & $\begin{array}{r}640 \\
2560 \\
\end{array}$ & $\begin{array}{r}0 \\
801\end{array}$ & $\begin{array}{r}0 \\
1280 \\
\end{array}$ & & & \\
\hline 15 & & 今 & 24 & Farmer & $\begin{array}{l}\text { Dec. } \\
27,48\end{array}$ & 40 & 1280 & 1280 & 40 & 320 & & & + \\
\hline 16 & & 今 & 69 & None & $\begin{array}{l}\text { Dec. } \\
\quad 1,48\end{array}$ & 36 & 2560 & 640 & 0 & 320 & 0 & 320 & $t$ \\
\hline 17 & & 우 & 65 & None & $\begin{array}{l}\text { Nov. } \\
28,48\end{array}$ & 11 & 640 & 10 & 0 & 10 & & & \\
\hline 18 & & 우 & 39 & None & $\begin{array}{c}\text { Dec. } \\
1,48\end{array}$ & 36 & 160 & 640 & 0 & 160 & & & \\
\hline 19 & & 우 & 13 & Student & $\begin{array}{l}\text { Dec. } \\
8,48 \\
\end{array}$ & 35 & 40 & 0 & 0 & 0 & & & \\
\hline 20 & & 우 & 28 & None & $\begin{array}{l}\text { Dee. } \\
10,48\end{array}$ & 30 & 320 & 160 & 40 & 80 & & & \\
\hline
\end{tabular}

WFR and CFT were performed following the methods published from the U.S. Army Medical School and R-aggl. T was made using our own method. ${ }^{1)}$ Three antigens, soluble (S), murine (M) and epidemic (E) were used in CFT and two, $M$ and E, in R-aggl. T. WFR for OX19 was more or less positive in all the samples tested and the titers were ranging from 
Table 2

SEROLOGICAL DIAGNOSIS OF MURINE TYPHUS PATIENTS IN NIIGATA PREPECTURE

\begin{tabular}{|c|c|c|c|c|c|c|c|c|c|c|c|}
\hline \multirow{2}{*}{ No. } & \multirow{2}{*}{ Name } & \multirow{2}{*}{ Sex } & \multirow{2}{*}{ Age } & \multirow{2}{*}{$\begin{array}{l}\text { Onset } \\
\text { of } \\
\text { disease }\end{array}$} & \multirow{2}{*}{$\begin{array}{c}\text { Days } \\
\text { onset } \\
\text { to } \\
\text { bleeding }\end{array}$} & \multirow{2}{*}{ W.F.R. } & \multicolumn{3}{|c|}{ C.F.T. } & \multicolumn{2}{|c|}{ R-Aggl } \\
\hline & & & & & & & $\mathrm{S}$ & $\mathbf{E}$ & $\mathbf{M}$ & $\mathbf{E}$ & $\mathbf{M}$ \\
\hline 1 & & 今 & 37 & $\begin{array}{l}\text { Jan. } \\
2,49\end{array}$ & 19 & 2560 & 160 & 40 & 160 & 10 & 80 \\
\hline 2 & & 우 & 50 & $\begin{array}{l}\text { Dec. } \\
19,48\end{array}$ & 31 & 2560 & 40 & 10 & 10 & 160 & \\
\hline 3 & & 令 & 42 & $\begin{array}{l}\text { Dec. } \\
25,48\end{array}$ & 25 & 5120 & 160 & 10 & 40 & 80 & $\overline{1280}$ \\
\hline 4 & & 우 & 19 & $\begin{array}{l}\text { Jan. } \\
22,49\end{array}$ & 7 & 160 & 80 & 0 & 20 & 40 & 160 \\
\hline 5 & & 今 & 41 & $\begin{array}{l}\text { Jan. } \\
17,49\end{array}$ & 12 & 80 & 40 & 10 & 40 & & \\
\hline 6 & & 今 & 24 & $\begin{array}{l}\text { Jan. } \\
20,49\end{array}$ & 9 & 640 & 80 & 0 & 40 & 160 & \\
\hline
\end{tabular}

* All the cases were a farmer.

$1: 2$ to $1: 5,120$. CFT for all antigens were positive in 16 cases and negative in 3 .

CFT for $S$ was positive with titers $1: 10-1: 2,560$ in 16 cases and negative in 1 case, CFT for $M$ was positive with titers $1: 10$ to $1: 1,280$ in 14 cases and negative in the other 5 cases, CFT for $\mathrm{E}$ was positive with titers $1: 20$ to $1: 320$ in 11 cases and negative in 8 cases. Generally the titer for $M$ was higher than that for $E$. They were diagnosed, therefore, as murine typhus cases. There was one sample, however, which showed the same titer for both $\mathrm{E}$ and $\mathrm{M}$. In such case the differentiation of murine from epidemic was impossible. Strong cross reaction, furthermore, was observed in 4 cases. In 2 cases, CFT was negative for both $\mathrm{E}$ and $\mathrm{M}$ and positive for $\mathrm{S}$ only. They were typhus fever but it was impossible to diagnose whether they were $\mathrm{E}$ or $\mathrm{M}$. In 2 other cases, the first samples were positive for $\mathrm{S}$ only and the second samples were positive for $\mathrm{S}, \mathrm{E}$ and $\mathrm{M}$ as described by Scoville ${ }^{2)}$ and Kitaoka. ${ }^{3)}$ Serum samples from the 3 CFT-negative cases were collected on the 9th, 14th and 35th day of illness respectively. If the collection of samples had been made more frequently, they might have shown positive results. Anyway, it should be emphasized that at least 3 samples from one case are to be tested during the entire course of the disease. In regard to R-aggl. T, 2 out of 3 cases tested were positive for $M$. They were diagnosed as murine typhus. The other one was negative in R-aggl. T. 
From foregoing results, it can be concluded that (1) 13 out of 19 cases were diagnosed as murine typhus, (2) 1 case was undeterminable whether it was murine or epidemic typhus and (3) 2 cases were typhus fever but not determined whether epidemic or murine because they were positive in CFT for S only. It would have been possible to get a definite answer on 3 undeterminable and 2 negative cases if the test blood samples had been collected more frequently.

3) Rickettsial isolation: Rickettsial isolation was undertaken from 3 cases No. 14, No. 15 and No. 16 as shown in Table 1. The blood samples were collected from those 3 cases while they were still at the febrile stage on 10th, 14th and 10th day of the disease respectively. An amount of 3 to $4 \mathrm{cc}$ of blood to be tested was inoculated intraperitoneally into each male guinea-pig (Fig-2). The rectal temperature was taken and the scrotal reaction was carefully observed. If any typhus suspected fever or Neill-Mooser's reaction (NMR) was seen in the guinea-pig inoculated, after a certain incubation period, the animal was sacrificed to find out rickettsia in the smear of tunica vaginalis testis and to transfer to the next passage. The serum was collected from the animals with or without typhus symptoms for making CFT which was observed for 2 or 3 weeks. If the animals did not show any typhus symptoms, blind passage was undertaken with the emulsion of the brain injecting into rats alternating with guinea-pigs because all the patients had serologically been diagnosed as murine typhus and albino rats were known to develop Maxcy's phenomenon. When the guinea-pigs developed typical murine typhus, it was very easy to transfer rickettsia into mouse, rat, guinea-pig, embryonated egg and Zinsser's slant ager. Three strains, Nos. 14, 15 and 16, were adapted in the yolk sac and the antigens were prepared from each of them. By CFT the antigens were confirmed to be Rickettsia typhi. The followings are the detailed descriptions of rickettsial isolation from those 3 cases.

The guinea-pigs of the first generation inoculated with the blood collected from the case No. 14 and the rats of the 2nd generation showed fever symptom only, while the guinea-pigs of the 3rd generation showed fever, positive Neill-Mooser's reaction and rickettsia in the smear of tunica vaginalis testis. Abundant rickettsia were found in the mice, rats, guineapigs, embryonated yolk sac and Zinsser's slant ager culture as shown in Fig. 2. 
Fig. 2 Isolation of Rickettsio typhi from a murine typhus case No. 14 on the 10th day of illness in Saitama Prefecture

(December 10th, 1948)

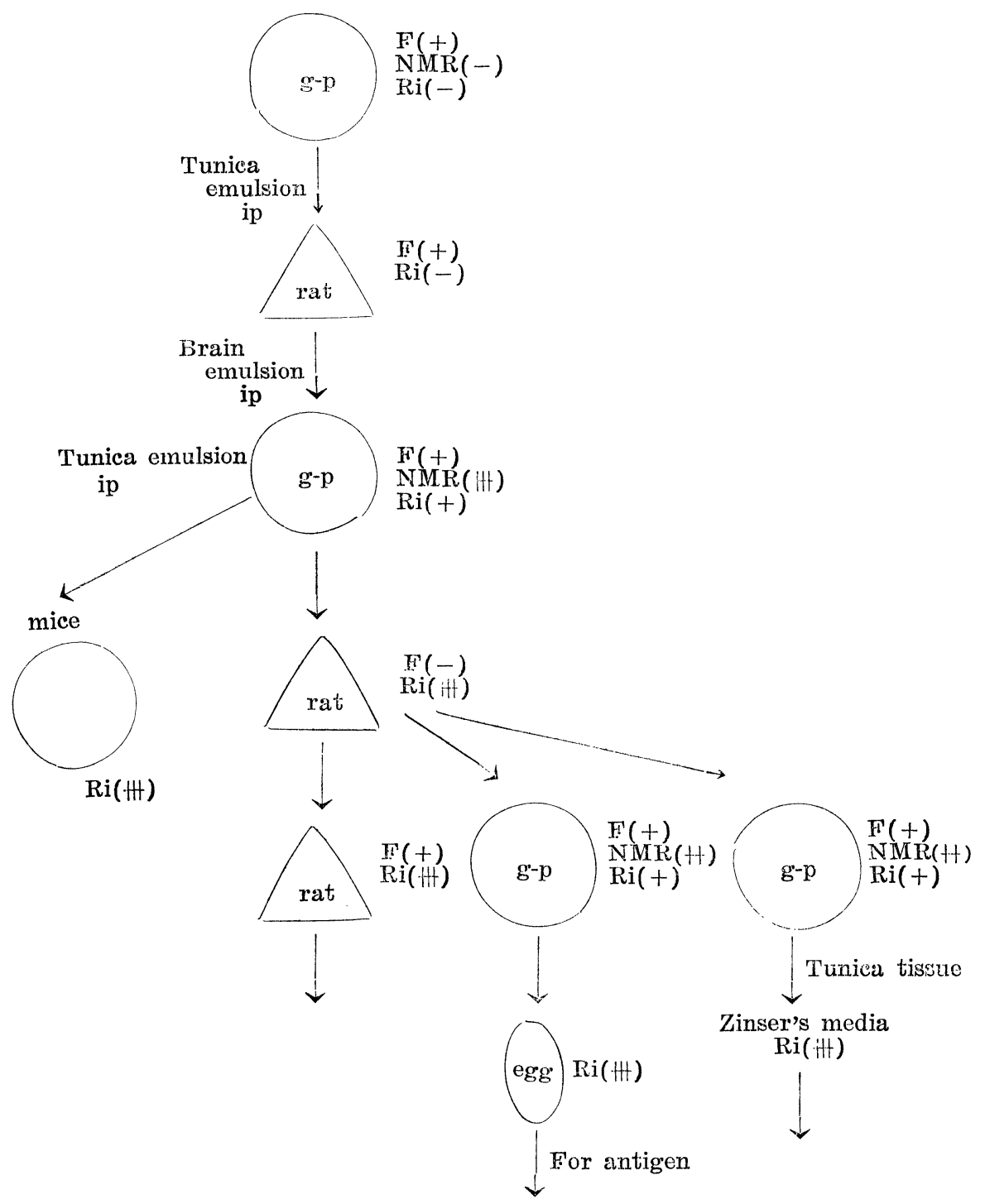

In regard to the strain No. 15, rickettsia was found definitely in the rat of the 6th generation of the blind passage alternating with guinea-pig. A pregnant rat was used in the second generation. It bore a baby after mild fever, the brain of which was removed for making inoculation into a 
guinea-pig of the 3rd generation in which fever developed though rickettsia was not found in the smear of tunica vaginalis testis and Neill-Mooser's reaction remained nagative. Rickettsia seems to pass through the placenta into the embryos if a pregnant rat is infected.

The guinea-pigs of the first generation inoculated with the blood collected from the patient No. 16 became feverish, and rickettsia was first demonstrated in the tunica smear of the third generation guinea-pigs which showed fever and positive Neill-Mooser's reaction. The strain was transfered to mice and rats. Rickettsia was found in them. Bleedings were made from the guinea-pigs inoculated with the three strains mentioned above to CFT against $M$ and $E$. All of the sera were positive against $M$. An antigen was prepared from the infected yolk sac. The strains were all identified as Rickettsia typhi.

B) Multiple occurrence of murine typhus cases in Niigata Prefecture.

From the middle of December 1948 to the end of January 1949, 6 typhus fever like cases occurred in Kashiwabara-dirstrict, Niigata Prefecture, 4 cases in Nalradori-village, 1 case each in Futada- and Hojovillages. The proportion of male to female was $3: 3$. The age distribution was from 15 to 50 years old. There exist many areas infected with scrub typhus along the rivers Shinano and Agano but no murine typhus has been reported in Niigata Prefecture. In 1946, when there was a large outbreak of epidemic typhus throughout Japan, epidemic typhus had also been reported in these districts among the laborers and the people in the low social class infested with lice. The first case, therefore was suspected as an epidemic typhus in this time, but no lice was found. Clinical symptoms and epidemiological data were contrary to the suspicion too. They occurred sporadically and there was no evidence of man to man or family infection. Numerous rats were found in each house. Six blood samples were taken from the patients on the 7 th to 25 th day of disease for running WFR, CFT and R. aggl. T.

The WFR was positive with titers ranging from $1: 80$ to $1: 5,120$ in all the test samples. In the CFT, 2 cases were positive for $M$ without cross reaction for $\mathrm{E}$, the other 3 cases were also positive for $\mathrm{M}$ with cross reaction for $E$ and the remaining one showed the same titer for both $E$ and $M$. In the R-aggl. T, 5 cases were positive for $M$. All of them were diagnosed serologically as murine typhus. Rickettsial isolation from 2 cases, No. 4 and No. 5, was attempted in guinea-pigs, rats, mice and 


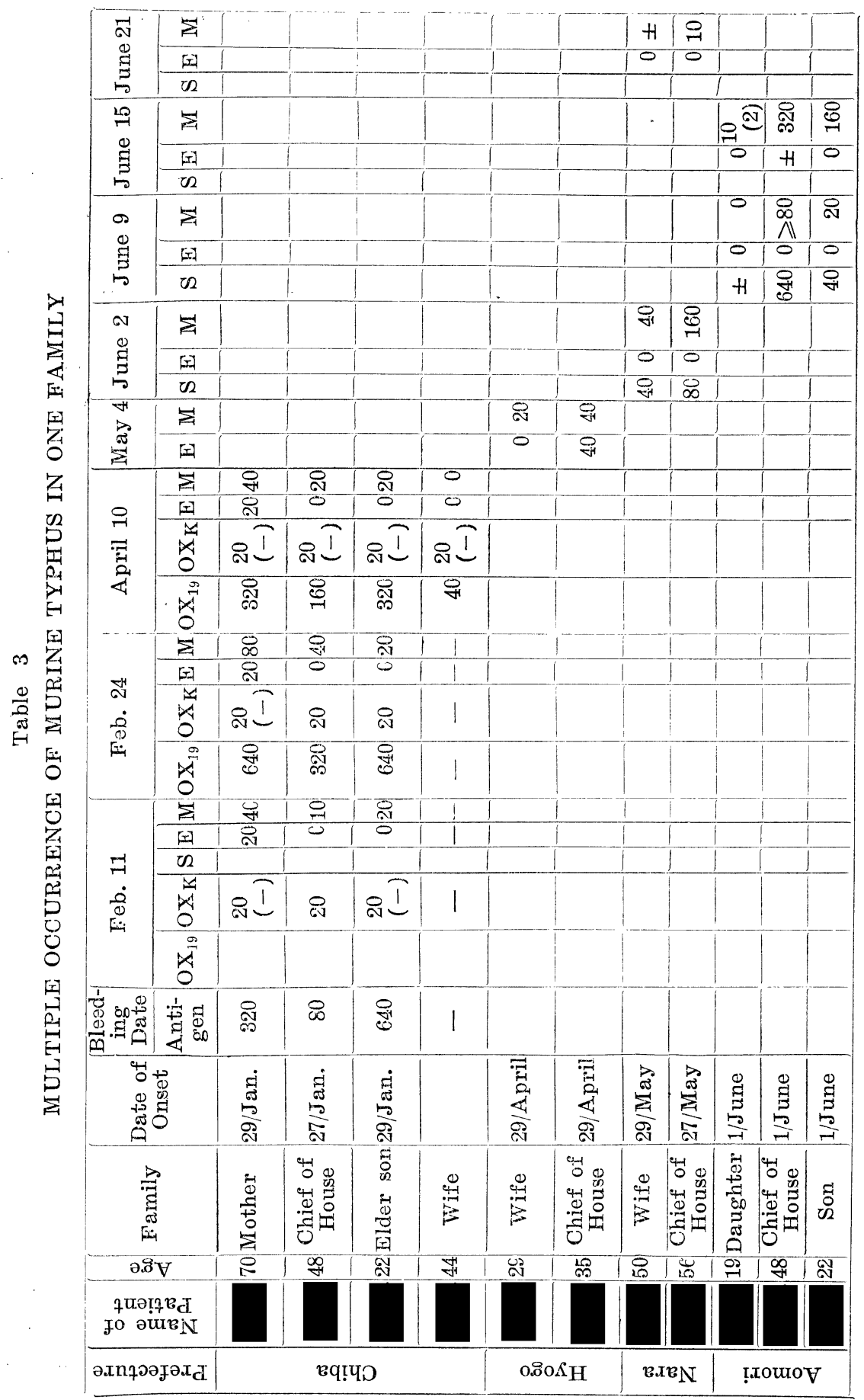


embryonated eggs but no positive results were obtained though the blood to be tested was taken at the febrile stage of the illness and the blind passages were performed in guinea-pigs, alternating with albino rats up to the 5 th generation.

C) Multiple occurrence of muxine typhus cases in one family.

The epidemic of louse-borne typhus broke out in Tokyo and Kanagawa areas in the beginning of January 1950. At the same time, 3 typhus fever like cases occurred in one family in Nakago-village, Chiba Prefecture near Tokyo. They complained of fever, headache, myalgia, anorexia, insomnia and rashes, and confined in bed. All the members of the family were quarantined as epidemic typhus was suspected.

This family belongs to a middle class farmers and their house is located far apart from the others in the village. No louse was found, and none of the family member made any trip through the epidemic typhus area. Many rats were found in the house. A rat was trapped and an isolation of Rickettsia iyphi was attempted but failed. The date of onset of the illness for each case was as follows: The house holder (age 48) on January 27th, 1950 and both his mother (age 70) and the eldest son (age 22) on January 29th. It can be assumed that 3 cases were infected almost simultaneously but not by case to case infection. His wife (age 44) and his second son (age 18) looked quite normal. Blood was taken from these 3 cases on three different occasions, February 11th, 24th and April 10th. WFR and CFT were made on each of them. They were diagnosed as murine typhus. The wife who looked normal was bled on April 10th for serological examinations. WFR on the specimen from the wife was positive with the titer 1:40 while the CFT and R-aggl. T were negative. Multiple occurrence of murine typhus in one family like this was observed in the other prefectures too: Saitama ( 2 cases), Hyogo ( 2 cases), Nara (2 cases) and Aomori (3 cases) during the typhus season as shown in Table 3. It is interesting to note that many murine typhus cases occurred nearly almost simultaneously in one family during the epidemic season of louse-borne typhus.

\section{DISCUSSION}

Louse-borne typhus is different from flea-borne typhus in the mode of spreading. It is said that there is no mass infection in one camp nor in a 
family. But there are some reports on multiple occurrence of murine typhus cases in a limitted area. For instance, Kasahara ${ }^{4}$ ) reported such multiple occurrence of murine typhus cases in Tokyo, which were confirmed by rickettsial isolation. There are many reports of two or three cases in one family. $\mathrm{Umeda}^{5)}$, Sakuno ${ }^{5)}, \mathrm{Ozaki}^{\mathrm{i})}$ and $\mathrm{Shimizu}^{8}$ ) reported such cases in Manchuria, Ogawa ${ }^{9)}$ in Northern China, Nakamura' ${ }^{10)}$, Enjoji $^{11)}$, Ro $^{12)}$, Azuma ${ }^{13)}$ and Inoue ${ }^{14)}$ in Korea, Kawahigashi ${ }^{15)}$ and Yoshimura ${ }^{16)}$ in Formosa, Iki ${ }^{17}$ (Kagawa), Asami ${ }^{18)}$ (Hyogo), Matsukawa ${ }^{1()}$ (Gifu), Kajikawa $^{21)}$ (Osaka) and Nagai22) (Kagawa) in Japan. Ochiai20) reported on 10 cases in one family during a period of two months in Nagoya which were murine typhus cases confirmed by isolation of the rickettsia. In view of these literatures, murine typhus seems to spread by case to case infection like epidemic typhus. Furthermore, it was experimentally confirmed by us that the murine typhus could be transmitted by lice. Murakami ${ }^{23}$ ) did not deny the possibility of the infection through lice in his paper made on the multiple occurrence in Okayama. However, it should be pointed out that multiple occurrence in one family was concurrent or quite independent infection if carefully observed and that the mode of spreading in murine typhus was quite different from epidemic typhus. The final diagnosis of typhus fever can only be attained by making CFT and R-aggl. $\mathrm{T}$ (Bengtson ${ }^{24,25)}$, Plot ${ }^{2 i)}$ and Kitaoka ${ }^{23)}$. But it is known that the pattern of the results obtained in serological tests is often modified by vaccination received prior to the infection (Sadusk ${ }^{30)}$, Zarafonetis ${ }^{31,32)}$ and Kitaoka ${ }^{28}$. The antibody for $S$ appeares earlier than that for $E$ or M in CFT of the typhus fever (Berge ${ }^{29)}$ and Kitaoka ${ }^{28)}$ ). All the cases mentioned above were examined by WFR, CFT and R-aggl. T and were diagnosed as murine typhus. Most of them showed no cross reaction for $\mathrm{E}$ while some showed strong cross reaction for both $\mathrm{E}$ and $\mathrm{M}$ and in a few cases it was impossible to make the differentiation of murine typhus and epidemic typhus as they showed the same titer for both $E$ and $M$. It is not clear why some had cross reaction while some did not. One must be carful to call such undeterminable case as an intermediate form of the typhus of the fever without having experimental basis to support the decision. In our opinion the appearance of an intermediate form is presumably due to individual factors rather than to the etiologic factors. It should be emphasized that test samples are collected at least three times during the course of disease, at the onset, 2 nd week and convalescent stage. 
For the isolation of rickettsiae from the murine typhus case, it is recommended to use guinea-pigs alternating with rats and mice. It should be confirmed in future that if rickettsia passes through the placenta of an infected pregnant rats into the foetus.

The multiple occurrence of murine typhus in Saitama Prefecture was presumably induced by performing to rat control without combined with dusting or spray of insecticide. Rat control should always be made combined with insect control especially in the area under epidemic of murine typhus as described by Hill ${ }^{38}$.

\section{SUMMARY}

1) From October to November in 1948, 20 typhus-fever-like cases were reported in one district of Saitama Prefecture. First they were considered epidemic typhus. Blood samples were taken from all cases and examined by WFR, CFT and R-aggl. T. Two cases (father and his son) were reported in one family. They were diagnosed as murine typhus by CFT and R-aggl. T. It is the first report on the murine typhus in Saitama Prefecture. From the epidemiological standpoint, there were no lice or any evidence for case to case infection. They were sporadic. No relation was observed between their occupations and the infection while numerous rats were seen in their houses.

Three strains of Rickettsia typhi were isolated from the blood samples of 3 cases taken at their febrile stage by transferring them into guineapigs alternating with rats and mice, or into embryonated eggs and Zinsser's slant ager culture. The antigens prepared from infected yolk sac were identified each as Rickettsia typhi.

The multiple occurrence of murine typhus was presumably due to the rat control without insect control which had been made just before the outbreak of murine typhus. It should be emphasized that the rat control should be combined with insect control. No cross reaction was observed in some cases while strong cross reaction in the other cases. It was impossible to differentiate epidemic typhus from murine because the CFT titer was equal for both $\mathrm{E}$ and $\mathrm{M}$. As to the reason why, it is not clear. It is presumably due to the individual factors rather than to the etiologic factors.

2) From December 1948 to January 1949, six typhus-fever-like cases were reported in one district of Niigata Prefecture. Epidemiological survey and 
serological tests were made for murine typhus. It is the first report on murine typhus in Niigata Prefecture. Rickettsial isolation was negative in 2 cases.

3) During the outbreak of epidemic typhus in Tokyo, Yokohama and others in the spring of 1950, three out of five members of one family suffered from the typhus-fever-like disease. They were considered to be espidemic typhus but serological test and epidemiological factor did not support it. Multiple occurrence of murine typhus in one family like this was reported in Hyogo (2 cases), Nara (2 cases) and Aomori (3 cases). However, there was no evidence for case to case infection. They were concurrent or quite independent infection.

Murine typhus in Niigata is now under investigation by Dr. Ito and Dr. Sasakawa in a larger scale.

\section{REFERENCE}

(1) Kitaoka, M. \& Inoue, H.: On the macroscopical rickettsia agglutination test on the hollow slide-glass. J.M.J., 3, 321-329, 1950.

(2) Scoville. A.B., Benett, B.S., Wertman, K. \& Gauld, R. L.: The serologic pattern in typhus fever. II Murine. A. J. Hyg., 47, 166-176, 1948.

(3) Kitaoka, M. and Inoue, H.: Serologic pattern in murine typhus fever. Sogo-Igaku, 7, 258-260, 1950. (in Japanese).

(4) Kasahara, S.: On the occurrenee of murine typhus fever in the central part of Tokyo and finding infected house-rats. Transactiones Societatis Pathologicae Japonicae, 29, 120-122, 1939 (in Japanese).

(5) Umeda, I.: Unknown eruptive disease occurring in Southern Manchuria. Jicchi-Igaku to Rinsho, 10, 937, 1930 (in Japanese).

(6) Sakuno, N. \& Ota, T.: On the family infection of Manchurian fever. Saikingaku Zasshi, No. 460, 433-437, 1934 (in Japanese).

(7) Ozaki, Y. \& Otsuka, I.: Epidemiological survey on the so-called Manchurian typhus fever in Shinkyo-City, 1933. Manshu-Igakkai Zasshi, 22, 319332, 1935 (in Japanese).

(8) Shimizu, G.: Statistical survey on murine typhus fever in Bujun. NipponDensenbyo-gakkai Zasshi, 560-576, 1936 (in Japanese).

(9) Ogawa, J. \& Nagatani, T.: On the family infection of murine typhus. Toykyo-Iji-shinshi, 2940, 2009-2010, 1935 (in Japanese).

(10) Nakamura, K. \& Ro, T.: On the family infection of murine typhus. Jikken-Iho, 245, 727-732, 1935 (in Japanese).

(11) Enjoji, S. \& Kin, H.: Murine typhus among children. Nippon-DensenbyoGakkai Zasshi, 10, 911-918, 1936 (in Japanese).

(12) Ro, T.: On the clinical observation of murine typhus cases in Heijo district, Korea. Nippon-Densenbyo-Gakkai Zasshi, 11, 679-710, 1937 (in Japanese).

(13) Azuma, Y. \& Inoue, O.: On the elinical observation of murine typhus patients in Korea during the period of last 5 years. Chosen-Igakkai Zasshi, 27, 1609-1610, 1937 (in Japanese). 
(14) Inoue, H. \& Kin, S.: Co-existence of epidemic and murine typhus cases in one family. Rinsho Naika-Gaku, 7, 196, 1939 (in Japanese).

(15) Kawahigashi, K.: On the family infection of two-week fever. TaiwanIgakkai Zasshi, 38, 79-85, 1939 (in Japanese).

(16) Yoshimura, K.: On the family infection of murine typhus (so-called twoweek fever) in Formosa. Nippon-Igaku oyobi Kenko-Hoken, 3245, 20512053; 3246, 2105-2108, 1941 (in Japanese).

(17) Iki, S. \& Ueno, M.: On a kind of eruptive febrile disease. Rinsho, 2, 245, 1925 (in Japanese).

(18) Asami, S. \& Daijo, T.: On the eruptive febrile disease in Hyogo-Ken. Tokyo-Iji-Shinshi, 2940, 1967-1975, 1935 (in Japanese).

(19) Matsukawa, S.: On the statistical observation of murine typhus (so-called Manchurian fever) in Mino-Machi, Gifu Prefecture. Byorigaku-Kiyo, 11, 85-91, 1936 (in Japanese).

(20) Ochiai, K., Nozaki, Y. \& Nakagawa, M.: On the 10 murine typhus eases in one family and the small epidemic. Isolation of rickettsia from patients, house-rats and rat-fleas. Nippon-Densenbyo-Gakkai Zasshi, 11, 948-949, 1937; Tokyo-Iri-Shinshi, 3016, 175-178, 1937 (both in Japanese).

(21) Kajikawa, N.: Murine typhus in Osaka Osaka-Iji-Shinshi, 9, 109-114, 1938 (in Japanese).

(22) Nagai, S., Nagamori, S., Ota, K., Takahashi, M., Kobayashi, O., Akazawa, T., Sasaki, R., Miyoshi, S. \& Hirota, Y.: On the family infection of murine typhus (Takamatsu fever). Jika-Zasshi, 46, 1453, 1950 (in Japanese).

(23) Murakami, S.: (Personal communication).

(34) Bengtson, I. A.: Complement fixation in endemic typhus fever. Pub. Health Rep. 56, 649-653, 1941.

(25) Bengtson, I. A.: Complement fixation in the rickettsial disease, technique of the test. Pub, Health Rep. 59, 402-405, 1944.

(26) Plotz, H.: Complement fixation in rickettsial disease. Science, 97, 20-21, 1943.

(27) Kitaoka, M., Shishido, R., Jo, K., Inoue, H., Ichikawa, T. \& Nishi, M.: Complement fixation test and R-aggl. test in epidemic and murine typhus fever. Nippon-Saikin-Gaku Zasshi, 3, 127, 1948 (in Japanese).

(28) Kitaoka, M.: On the complement fixation test in epidemic and murine typhus. Sogo-Igaku, 6, 829-833, 1949 (in Japanese).

(29) Berge, T. O.: Employment of solube antigen in screening test for the typhus complement fixation in endemic typhus fever. Pub. Health Rep. 63, 529-537, 1948.

(30) Sadusk, J. F.: Typhus fever in the United States Army following immunization. J.A.M.A., 132, 1192-1199, 1947.

(31) Zarafonetis, C.T.D.: Serologic studies in typhus vaccinated individuals. J. Immunol., 51, 365-374, 1945.

(32) Zarafonetis, C.T.D., Ecke, R.S., Yeomans, A., Murray, E.S. \& Snyder, J. C.: Serologic studies in typhus vaccinated individuals. III. J. Immunol., $53,15-30,1946$.

(33) Hill E.L., Morlan H.B. Uttreback B.C. and Schubert J.H.: Evaluation of country-wide D.D.T. dusting operations in murine typhus control (1946 through 1949). Amer. J. Pub. Health \& Nation's Health, 41, 396-401, 1951. 